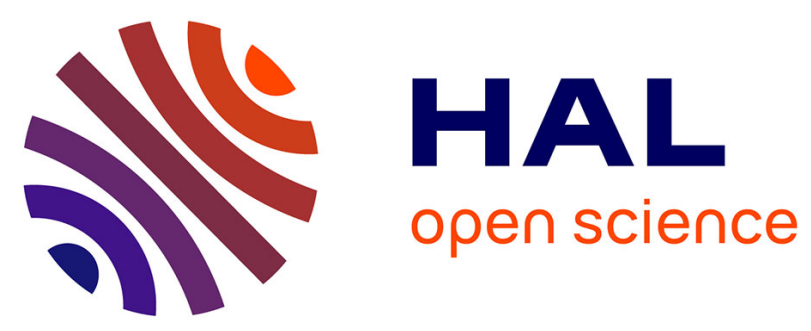

\title{
A comprehensive review of genomic landscape, biomarkers and treatment sequencing in castration-resistant prostate cancer
}

Thomas Seisen, Morgan Roupret, Florie Gomez, Gabriel G. Malouf, Shahrokh F. Shariat, Benoit Peyronnet, Jean-Philippe Spano, Geraldine Cancel-Tassin, Olivier Cussenot

\section{To cite this version:}

Thomas Seisen, Morgan Roupret, Florie Gomez, Gabriel G. Malouf, Shahrokh F. Shariat, et al.. A comprehensive review of genomic landscape, biomarkers and treatment sequencing in castrationresistant prostate cancer. Cancer Treatment Reviews, 2016, 48, pp.25-33. 10.1016/j.ctrv.2016.06.005 . hal-01435014

\section{HAL Id: hal-01435014 https://hal-univ-rennes1.archives-ouvertes.fr/hal-01435014}

Submitted on 6 Mar 2017

HAL is a multi-disciplinary open access archive for the deposit and dissemination of scientific research documents, whether they are published or not. The documents may come from teaching and research institutions in France or abroad, or from public or private research centers.
L'archive ouverte pluridisciplinaire HAL, est destinée au dépôt et à la diffusion de documents scientifiques de niveau recherche, publiés ou non, émanant des établissements d'enseignement et de recherche français ou étrangers, des laboratoires publics ou privés. 
A comprehensive review of genomic landscape, biomarkers and treatment sequencing in castration-resistant prostate cancer

Thomas Seisen, ${ }^{1,2}$ Morgan Rouprêt, ${ }^{1,2,}$ Florie Gomez, ${ }^{3}$ Gabriel G. Malouf, ${ }^{4}$ Shahrokh F. Shariat, ${ }^{5}$ Benoit Peyronnet, ${ }^{6}$ Jean-Philippe Spano, ${ }^{4}$ Géraldine Cancel-Tassin, ${ }^{2}$ and Olivier Cussenot $^{2,7}$.

\section{Affiliations :}

${ }^{1}$ Academic Department of Urology of La Pitié-Salpétrière, Assistance-Publique Hôpitaux de Paris; Faculté de Médecine Pierre et Marie Curie, University Paris 6, 75013, Paris, France

${ }^{2}$ Institut Universitaire de Cancérologie, Pierre et Marie Curie, University Paris 6, GRC $\mathrm{n}^{\circ} 5$, CeRePP/ONCOTYPE-URO, 75013, Paris, France.

${ }^{3}$ Department of urology, CHC Liege, Liège, Belgium

${ }^{4}$ Academic Department of Medical Oncology of La Pitié-Salpétrière, Assistance-Publique Hôpitaux de Paris; Faculté de Médecine Pierre et Marie Curie, University Paris 6, GRC n ${ }^{\circ}$, ONCOTYPE-URO, 75013, Paris, France

${ }^{5}$ Academic Department of Urology and Comprehensive Cancer Center, Vienna General Hospital, Medical University of Vienna, Vienna, Austria

${ }^{6}$ Academic department of Urology, CHU Rennes and University of Rennes, France

${ }^{7}$ Academic Department of Urology of Tenon, Assistance-Publique Hôpitaux de Paris; Faculté de Médecine Pierre et Marie Curie, University Paris 6, 75013, Paris, France

Words count : Abstract (198), Manuscript (3,217)

Tables (3), Figures (3), Supplemental material (4)

Key words (MeSH): Prostate Neoplasms, Castration-Resistant ; Biomarkers ; Receptors, Androgen ; Genetic ; Abiraterone acetate ; MDV 3100 ; Docetaxel ; Cabazitaxel

*Corresponding author: Morgan Rouprêt, $\mathrm{MD}, \mathrm{PhD}$

Academic Urology Department, Hôpital Pitié 47-83 bvd de l'Hôpital, 75013 Paris, France

E-mail: morgan.roupret@psl.aphp.fr 


\section{A comprehensive review of genomic landscape, biomarkers and treatment sequencing in castration-resistant prostate cancer}

\section{Abstract}

Hormone-naïve prostate cancer and its castration-resistant state (CRPC) are clinically and genetically heterogeneous diseases. From initiation of prostate carcinogenesis to its evolution towards therapeutic resistance, various combinations of genetic and epigenetic events occur. Schematically, progression to CRPC could be divided in two distinct pathways, either dependent or independent of the androgen receptor activity. Nevertheless, because the better knowledge of the genetic landscape of CRPC is under way, limited clinical applications are available at the moment, underlying the usefulness of prognostic and predictive biomarkers in daily practice. Despite the promising prognostic value of circulating tumor cells, no biomarker has been currently validated as a surrogate for overall survival in CRPC patients. Inversely, considerable interest has been generated with the recent finding of the splice variant $\mathrm{AR}-\mathrm{V} 7$ that allows to predict resistance to abiraterone acetate and enzalutamide. However, other predictive biomarkers would be necessary to accurately guide personalized sequencing of CRPC treatment, which now includes numerous possibilities based on the six validated drugs, without accounting for those currently under investigation in the ongoing randomized controlled trials. As a consequence, only rational sequencing, which consists in choosing an agent that is not expected to have cross-resistance with previous therapy, can be currently advised. 


\section{Introduction}

Hormone-naïve prostate cancer (HNPC) and its castration-resistant state (CRPC) are clinically and genetically heterogeneous diseases [1]. It is now well-established that some patients diagnosed with metastatic HNPC will rapidly progress to the lethal CRPC phenotype while others will show long-term and durable response to androgen deprivation therapy. Preliminary reports suggest that such a transition from HNPC to CRPC might be driven by a wide range of genetic events leading to distinct progression pathways either dependent or independent of the androgen receptor (AR) activity [1-4].

Because of the greater understanding of CRPC biology, docetaxel (DCT) based treatment landscape has dramatically changed over last years. New systemic therapies, including the androgen biosynthesis inhibitor abiraterone acetate (AA) $[5,6]$ and the next-generation androgen receptor antagonist enzalutamide (ENZ) $[7,8]$ have demonstrated to prolong overall survival (OS) in both post- and, more recently, pre-DCT settings (Figure 1). Along with AA and ENZ, the bone targeted agent alpha emitter Radium 223 [9] and the immunotherapeutic sipuleucel-T[10] are also effective treatment options for the management of chemotherapynaïve patients while the taxoid cabazitaxel (CZT) [11] remains the standard of care for those pretreated with DCT. Sequencing all these innovative agents according to individual characteristics is now the challenge that physicians face in daily practice. Interestingly, there is intensive research to develop prognostic and predictive biomarkers for guiding clinical decision making and achieve optimal medical management of CRPC [12,13]. Therefore, our purpose was to describe the current knowledge of CRPC genomic landscape and to summarize the established and potential biomarkers as well as available evidence for treatment sequencing of patients diagnosed with metastatic disease. 


\section{From HNPC to CRPC}

\section{Genetic landscape of HNPC}

The earliest molecular events commonly reported in human prostate carcinogenesis are the loss of $8 \mathrm{p} 21$ region including NKX3 locus, the CpG island promoter methylation of GSTP1 gene, and particularly, androgen driven gene fusions (ETS positive) such as TMPRSS2-ERG fusion gene [14]. Through this ETS positive pathway, deletions at 10q24 region including PTEN locus and gains at $8 \mathrm{q} 24$ region including cMyc locus have been shown to foster further disease progression [14].

Alternatively, mutations of the SPOP gene have been recently identified as a key genomic event involved in the natural history of HNPC without any androgen driven gene fusions [14]. Indeed, these mutations result in the inability of the tumor cells to bind and promote the degradation of SRC-3, leading to increased androgen signaling. Through this ETS negative pathway, further disease progression might be induced by the deletion or the silencing of CDH1 gene [14]. More evidence to support distinct ETS positive and negative pathways has been recently reported by Grasso et al, who demonstrated that deregulations of ETS2 were specifically involved in growth of tumors with TMPRSS2-ERG fusion gene whereas disruptions of CDH1 might define a subtype of fusion gene free tumors (Figure 2) [2].

\section{Chromoplexy and chromotripsis models}

From initiation of HNPC to its progression towards therapeutic resistance and death, various combinations of genetic and epigenetic events occur (Figures 3A and 3B). Next generation sequencing of prostate cancer prior to and following androgen deprivation therapy has dramatically helped to identify important androgen-regulated pathways or genes that may be reactivated in CRPC [15]. Specifically, chromosomal rearrangements, amplifications, deletions, or point mutations and DNA methylation alterations allow for emerging aggressive 
clones [16]. These mechanisms involved in progression to the lethal stages are usually described according to the chromoplexy model, which drives the punctuated progression of HNPC and induces the formation of disrupted cancer genes such as ERG fusion with TMPRSS2, NKX3-1, TP53, RB1, CDKN13 and PTEN [17]. Alternatively, the chromotripsis model, based on high genetic instability with numerous chromosomal rearrangements and hypermutational status, has been proposed to explain the catastrophe scenario related to terrible disease evolution [18]. The chromoplexy and chromoptripsis phenomenons are summarized in Supplemental Table 1 and Figure 1.

\section{Genetic aspects of pathways involved in the progression to CRPC}

At the bio-pathological level, progression to CRPC could be divided in two schematic pathways [19]. The more frequent one remains dependent of the AR activity, which binds and drives genes characterized by AR genomic signature with androgens response elements sequences such as PSA or TMPRSS2. The second one is independent of AR activity, and is characterized by loss of differentiation towards an epithelial/mesenchymal transition (EMT) or towards hybrids tumors with trans-differentiation harboring neuroendocrine features according to the ontogenic origin of prostatic gland (Supplemental Figures 2A and 2B) [20].

\section{Androgen receptor activity dependent pathway}

Historically, the residual concentration of androgens after hormonal castration was seen as an event without any consequence, and resistance was considered to be related to androgenindependent mechanisms. However, the recent discovery of the efficacy of next-generation drugs targeting androgen-dependent AR signaling through inhibition of either AR ligandbiding (ENZ) or androgen synthesis (AA) supports the view of the activity of the AR pathway during progression to the CRPC phenotype. Schematically, two non-exclusive mechanisms 
have been described to explain the maintenance of such AR activity with low circulating testosterone levels after castration.

The first one is logically associated to local synthesis of ligand to AR. A number of genes involved in androgen metabolism such as AKR1C3 and SRD5A1 are deregulated and overexpressed in CRPC compared to HNPC, leading to greater in situ concentrations of testosterone [21]. This mechanism is supported by the recent randomized clinical trials comparing AA versus placebo, which have demonstrated that CRPC is still hormone sensitive when using this androgen biosynthesis inhibitor additionally targeting both intra tumoral and extra gonadal biosynthesis of androgens by inhibiting the critical enzyme CYP17A1 [5,6].

The second mechanism involved in the progression to CRPC through the AR pathway is a ligand independent constitutive activation of the AR itself. Beyond the AR gene activating mutations, deregulation of co-activators and repressors or alternative splicing of AR, and other recurrent mutations in multiple histone modifying genes including MLL2 gene have been recently identified to explain over expression of the AR-mediated signaling [2]. Similarly to AA clinical trials, randomized placebo controlled data obtained for ENZ provides clinical support to the implication of such altered pathway $[7,8]$. In addition to its competitive antagonist effect, ENZ has been demonstrated to display ligand independent anti-tumor activity by inhibiting nuclear translocation of AR and impairing both DNA binding to androgen response elements and recruitment of co-activators [22].

\section{Androgen receptor activity independent pathway}

The cell plasticity with dedifferentiation leading to proliferation, apoptosis resistance and EMT is alternatively involved in the progression to CRPC through the AR activity independent pathway, even though some clones might still be dependent on AR signaling [23]. Activation of the EMT program is characterized by the loss of E-cadherin and the gain 
of mesenchymal markers such as Vimentin and N-cadherin, which increases the migratory ability of the cells and contribute notably to the interaction of tumors cells with the microenvironment at the bone [24-26]. Such a phenomenon leads to the activation of a set of transcription factors including Twist and Snail, and is orchestrated by epigenetic remodeling involving the Polycomb complex [27].

All these molecular events are driven by key regulators including Myc and EZH2, which are deregulated either directly by genetical events or indirectly by epigenetical upstream events such as ERG overexpression or specific microRNA activation [28,29]. Notably, new insights in such a signalling pathway include regulation of Myc and EZH2 expressions by miR101/miR449 and miR101/miR26, respectively [28,29]. Other microRNAs have been related to CRPC biology, including miR125b/miR146/miR205 for androgen independent growth, miR21/miR221/miR15a for migration or invasion ability and miR20a/miR32/miR23 for apoptosis resistance [30]. Although the better knowledge of the genomic events leading to CRPC progression is under way, limited clinical applications are available at the moment, underlying the usefulness of prognostic and predictive biomarkers in daily practice. 


\section{Prognostic biomarkers in CRPC}

Prognostic biomarkers in CRPC allow to predict outcomes preceding or following treatment without necessarily providing evidence regarding potential sensitivity to a given agent [31,32]. A synthesized list of pre- and post-treatment prognostic biomarkers of interest in the management of CRPC is provided in Table 1. Many of these clinical or biological characteristics have been used as eligibility criteria for inclusion in randomized clinical trials designed to assess effectiveness of drugs under development in the field of CRPC. Specifically, the finding of five or more circulating tumor cells (CTCs) prior to the initiation of cytotoxic chemotherapy is associated with inferior OS while the decline of CTCs count below five has been demonstrated to result in increased OS [31,32]. Goldkorn et al have also confirmed the prognostic value of CTCs at baseline and before cycle two in a large DCTbased prospective cohort [33]. Of note is that the conversion from unfavorable to favorable CTCs count in DCT-resistant patients treated with AA or ENZ might prolong life expectancy [34,35]. Furthermore, a biomarker panel containing CTCs number has been shown to meet Prentice criteria for surrogacy of OS at the individual-patient level [36]. In addition, CTC visualization may enable a direct measurement of the underlying tumor biology. However, one drawback of the CTCs detection using the current CellSearch ${ }^{\circledR}$ technology is the lack of sensibility within CRPC setting, limiting its clinical interest [32]. As such, other liquid biopsy techniques including circulating cell-free tumor DNA may help to identify genomic alterations and track patient's genomic landscape over time to assess individual prognosis and adapt further treatment strategies. [37,38]

The vast majority of other clinical and biological prognostic biomarkers of CRPC have been validated and included in nomograms, which help physicians to estimate survivals using tumor's and patient's characteristics. Originally, PSA based testing results, performance status (PS) score, and hemoglobin level have been combined with age, albumin, LDH or ALP 
levels, Gleason score, pain intensity and metastases characteristics in different prognostic models $[31,39,40]$. Nevertheless, emergence of new treatment options in CRPC requests constant re appraisal of the clinical interest to use such biomarkers. Based on the prospective data obtained from ALLIANCE and ENTHUSE trials, Halabi et al. have recently developed and validated an updated nomogram for predicting survival in men with metastatic CRPC receiving first line chemotherapy [41]. This model was designed to incorporate wellestablished biomarkers such as PS score and PSA, albumin, LDH, ALP or hemoglobin levels but also new variables of interest such as metastatic site and and opioid analgesic use [42]. Accordingly, the prognostic value of metastatic site has been confirmed by Pond et al, based on the data of the TAX 327 trial [43].

More recently, expression of molecular biomarkers in whole-blood has been found to correlate with CRPC outcomes [44,45]. Ross et al. have assessed a panel of 168 inflammation- and prostate-related genes using PAXgene/TaqMan systems and RT-PCR to detect RNA transcripts and prostate cancer-enhanced RNA messenger, respectively [44]. A 6gene model separating patients into 2 risk groups according to their signature has been developed to help physician with prognostication of CRPC. Interestingly, this nomogram outperformed those exclusively based on clinicopathologic factors by showing greater accuracy using ROC curve analysis. Danila et al. have selected a different panel of prostaterelated genes including KLK3, KLK2, HOXB13, GRL2 and FOXA1 detected by multiplex RT-PCR [45]. After combining the results of gene profile with CTCs counts, risk group were defined to pinpoint patients with poor prognosis. This RT-PCR assay detecting prostatespecific RNA in whole blood associated with CTCs count is currently being prospectively tested as a prognostic factor and response indicator [45]. Loss of PTEN expression has also been reported to be associated with worse survival [46] and analyses of extracellular microRNAs embedded in circulating exomes revealed that plasma exomal miR-1290 and 
miR-375 could be promising prognostic biomarkers for CRPC patients [47]. Although none of them has been fully validated as a surrogate for OS, a wide range of prognostic biomarkers as well as nomograms are currently available to assess disease evolution risk in patients diagnosed with CRPC [48]. In addition, different predictive biomarkers seems to be also promising. 


\section{Predictive biomarkers in CRPC}

Predictive biomarkers can be clinical (e.g. prior exposure to a specific therapy, response to treatment), hormonal (e.g. serum testosterone levels), or molecular determinants (e.g. AR overexpression, increased biosynthesis of androgens, splice variants and mutations of AR, altered PTEN signaling, translocation allowing ETS transcription to be under control of androgens) that are associated with sensitivity or resistance to a specific treatment [32]. Specifically, considerable interest has been generated with the recent report on the splice variant AR-V7 [49]. Indeed, Antonarakis et al have demonstrated that the expression of such AR-V7 variant was correlated with the response to AA or ENZ [49]. This novel predictive biomarker has emerged after the analysis of CTCs in 62 patients treated prospectively with AA $(n=31)$ or ENZ $(n=31)$ for mCPRC. Interestingly, AR-V7 expression was correlated with treatment resistance to AA or ENZ, including shorter biochemical progression-free survival (PFS), radiological PFS and OS, compared to patients without AR-V7 expression. These response indicator biomarkers include also pharmacodynamics or imaging factors that typically show a change after treatment has occurred, without necessarily indicating that this change is in relation with a patient benefit [50-53]. Specifically, PSA level decline and tumor size changes according to RECIST criteria are two examples of them[31,32,54] but other imaging biomarkers are currently emerging. Indeed, the Prostate Cancer Working Group 2 (PCWG2) criteria and the bone scan index (BSI) developed at the MSKCC are other promising tools $[32,55]$. This lastly mentioned quantitative measurement of the tumor burden, as a percentage of the skeletal mass, is able to take into account increase in size of bone lesions. ${ }^{14}$ A doubling BSI is associated with a 2-fold increase risk of death but this imaging biomarker has to be validated in phase III clinical trials [56]. Investigators of COU-AA-302 trial have also proposed radiographic PFS as a response biomarker in metastatic CRPC considering that it was highly consistent and highly associated with OS [57]. Also, ${ }^{18} \mathrm{~F}$ - 
fluorodeoxyglucose (FDG)-PET scan seems to be another imaging technique with better performance to detect early metastases compared to bone scan. Its prognostic significance is under evaluation as well as its value as response indicator. Table 2 summarizes the biomarkers with potential predictive value on response, patients benefit and candidate for surrogate end-points. Despite the emergence of these prognostic and predictive biomarkers in CPRC, a particular difficulty arising with the new agents available is the optimal sequence to administer them. 


\section{Sequential administration of new agents in CRPC}

To date, only few clinical trials attempted to assess the impact of different sequences of new agents such as AA, ENZ and CZT by using retrospective post-hoc anlyses with inherent bias. Specifically, the administration of AA after resistance to DCT followed by ENZ, was tested in 38 patients included in the phase 3 AFFIRM trial [56]. Because of a PSA decline $\geq 50 \%$ in only 3 patients and a median PFS of 2.7 months, this study suggested a potential crossresistance between AA and ENZ wich was confirmed in an other report [58]. The reverse sequence with ENZ after DCT and AA failure showed similar results with low response rates and short PFS [59-64]. The cross-resistance between AA and ENZ could be explained by increased levels of $\mathrm{AR} \triangle \mathrm{LBD}$ observed after the use of both drugs $[65,66]$.

Inversely, the administration of AA following synthetic oestrogen diethylstilboestrol (DES), was effective in a pre- and post-DCT setting [67]. Indeed, the reponse rates and time to progression were similar in the groups of DES-naïve or pre-treated patients in both settings. Consequently, AA seems to maintain antitumour activity in men with CRPC after DES exposure. In addition, effectivness of CZT has also been assessed in a sequencing trial including patients previously treated with DCT and next generation endocrine agents such as AA and ENZ [68]. Interestingly, prolonged OS and PFS were observed in this cohort of patients and such results were confirmed in other recent studies [69-71]. Because the AR amino-terminal domain has been previously reported to be critically important for the tubulin binding agent activity, one could hypothesize that the AA and ENZ resistant AR splice variants, lacking only the carboxy-terminal ligand-binding domain terminal, would still be inhibited by CZT [72]. This has been confirmed by recent findings which demonstrated that efficacy of CZT for CRPC was independent of the presence of AR-V7 in circulating tumor cell [73]. However, these finding might not apply to DCT considering that men receiving AA before DCT are more likely to progress on DCT and less likely to achieve a PSA response 
that AA-naïve patients [70,74-78]. In addition, large multicenter studies failed to show any signifcant difference in the clinical outcomes of third line treatment with AA, ENZ or CZT regardless of previous therapy delivered [79], whereas in a less advanced treatment setting, the prospective evidence from the recent TERRAIN trial support the use of ENZ rather than bicalutamide in patients with asymptomatic or midly symptomatic CRPC [80]. Supplemental Figure 3 shows options of targeting CRPC according to the activation of AR.

It is noteworthy that the recent results of the CHAARTED [81] and STAMPEDE [82] trials may also change the treatment landscape and sequencing of CRPC, as the use of DCT has been advocated in the last NCCN guidelines [83] to treat patients with metastatic HNPC, especially those with high-volume disease - despite the inconclusive post-hoc analyses from the GETUG-AFU 15 trial [84]. Nonetheless, DCT used as a second line therapy after AA for CRPC retains reasonable activity [85] (Table 3).

Finally, new drugs are currently emerging, adding even more confusion to the sequential treatment of CRPC [86]. Ongoing preclinical studies found new therapeutic targets such as signal transducer and activator of transcription 3 (STAT3) [87], while novel PI3K/AKTtargeted drugs associated with androgen deprivation therapy have shown promising results in CRPC models [88].

As a consequence, robust data on the best sequencing strategy for CRPC are growingly lacking. The absence of validated surrogate for OS in CRPC makes it difficult to conduct sequencing trials [89]. In addition, no agent has actually been developed with a companion predictive biomarker that may help to choose among the numerous possible sequences based on the six validated therapies for CRPC. Thus, several strategies using either the most active or least toxic agent first could be used but the rational sequencing, which consists in choosing an agent that is not expected to have cross-resistance with previous therapy in preference to one that may, appears to be more reasonable [90]. Because estimated median survival time of 
CRPC patients is approximately 40 months from diagnosis, it is likely that many of them will not live long enough to receive all these systemic therapies in sequence, and one additional issue of recent progress will be to identify those that could be used in combination based on the assessment of biomarkers derived from fundamental and clinical research. 


\section{Conclusion}

Stratifying patients with CRPC to receive next-generation drugs targeting the AR activity dependent or independent pathways remains an unmet need. Furthermore, designing novel therapies is currently a challenge at the crossroads of several fields including tumor genetics and epigenetics as well as micro-environmental changes. The main reason is simply related to the spatio-temporal evolution of prostate cancer cells towards such highly variable pathways. A comprehensive characterization of all these processes, simultaneously, all along the development of lethal CRPC in a defined patient remains unknown, although next-generation sequencing has dramatically helped to define the landscape of aggressive CRPC variants but also to find prognostic and predictive biomarkers.

Conflict of interest: The authors have no conflict of interest to disclose 


\section{References}

[1] Barbieri CE, Tomlins SA. The prostate cancer genome: perspectives and potential. Urol Oncol 2014;32:53.e15-22.

[2] Grasso CS, Wu Y-M, Robinson DR, Cao X, Dhanasekaran SM, Khan AP, et al. The mutational landscape of lethal castration-resistant prostate cancer. Nature 2012;487:239-43.

[3]Beltran H, Rubin MA. New strategies in prostate cancer: translating genomics into the clinic. Clin Cancer Res 2013;19:517-23.

[4] Gomella LG. Prostate cancer genomics: understanding the new landscape. Can J Urol 2014;21:7091.

[5] de Bono JS, Logothetis CJ, Molina A, Fizazi K, North S, Chu L, et al. Abiraterone and increased survival in metastatic prostate cancer. N Engl J Med 2011;364:1995-2005.

[6] Ryan CJ, Smith MR, Fizazi K, Saad F, Mulders PFA, Sternberg CN, et al. Abiraterone acetate plus prednisone versus placebo plus prednisone in chemotherapy-naive men with metastatic castration-resistant prostate cancer (COU-AA-302): final overall survival analysis of a randomised, double-blind, placebo-controlled phase 3 study. Lancet Oncol 2015;16:15260 .

[7] Scher HI, Fizazi K, Saad F, Taplin M-E, Sternberg CN, Miller K, et al. Increased survival with enzalutamide in prostate cancer after chemotherapy. N Engl J Med 2012;367:1187-97.

[8] Beer TM, Armstrong AJ, Rathkopf DE, Loriot Y, Sternberg CN, Higano CS, et al. Enzalutamide in metastatic prostate cancer before chemotherapy. $N$ Engl J Med 2014;371:424-33.

[9] Parker C, Nilsson S, Heinrich D, Helle SI, O’Sullivan JM, Fosså SD, et al. Alpha emitter radium-223 and survival in metastatic prostate cancer. N Engl J Med 2013;369:213-23.

[10] Kantoff PW, Higano CS, Shore ND, Berger ER, Small EJ, Penson DF, et al. Sipuleucel$\mathrm{T}$ immunotherapy for castration-resistant prostate cancer. N Engl J Med 2010;363:411-22.

[11] de Bono JS, Oudard S, Ozguroglu M, Hansen S, Machiels J-P, Kocak I, et al. Prednisone plus cabazitaxel or mitoxantrone for metastatic castration-resistant prostate cancer progressing after docetaxel treatment: a randomised open-label trial. Lancet 2010;376:1147-54.

[12] Kohli M, Qin R, Jimenez R, Dehm SM. Biomarker-based targeting of the androgenandrogen receptor axis in advanced prostate cancer. Adv Urol 2012;2012:781459.

[13] Loriot Y, Massard C, Fizazi K. One size does not fit all: can we choose the best sequence of treatment in asymptomatic castration-resistant prostate cancer patients? Eur Urol 2014;66:653-4.

[14] Barbieri CE, Demichelis F, Rubin MA. Molecular genetics of prostate cancer: emerging appreciation of genetic complexity. Histopathology 2012;60:187-98. 
[15] Rajan P, Sudbery IM, Villasevil MEM, Mui E, Fleming J, Davis M, et al. Nextgeneration sequencing of advanced prostate cancer treated with androgen-deprivation therapy. Eur Urol 2014;66:32-9.

[16] Berger MF, Lawrence MS, Demichelis F, Drier Y, Cibulskis K, Sivachenko AY, et al. The genomic complexity of primary human prostate cancer. Nature 2011;470:214-20.

[17] Baca SC, Prandi D, Lawrence MS, Mosquera JM, Romanel A, Drier Y, et al. Punctuated evolution of prostate cancer genomes. Cell 2013;153:666-77.

[18] Stephens PJ, Greenman CD, Fu B, Yang F, Bignell GR, Mudie LJ, et al. Massive genomic rearrangement acquired in a single catastrophic event during cancer development. Cell 2011;144:27-40.

[19] Karantanos T, Evans CP, Tombal B, Thompson TC, Montironi R, Isaacs WB. Understanding the mechanisms of androgen deprivation resistance in prostate cancer at the molecular level. Eur Urol 2015;67:470-9.

[20] Lapuk AV, Wu C, Wyatt AW, McPherson A, McConeghy BJ, Brahmbhatt S, et al. From sequence to molecular pathology, and a mechanism driving the neuroendocrine phenotype in prostate cancer. J Pathol 2012;227:286-97.

[21] Egan A, Dong Y, Zhang H, Qi Y, Balk SP, Sartor O. Castration-resistant prostate cancer: adaptive responses in the androgen axis. Cancer Treat Rev 2014;40:426-33.

[22] Tran C, Ouk S, Clegg NJ, Chen Y, Watson PA, Arora V, et al. Development of a secondgeneration antiandrogen for treatment of advanced prostate cancer. Science 2009;324:787-90.

[23] Li P, Yang R, Gao W-Q. Contributions of epithelial-mesenchymal transition and cancer stem cells to the development of castration resistance of prostate cancer. Mol Cancer 2014;13:55.

[24] Jennbacken K, Tesan T, Wang W, Gustavsson H, Damber J-E, Welén K. N-cadherin increases after androgen deprivation and is associated with metastasis in prostate cancer. Endocr Relat Cancer 2010;17:469-79.

[25] Gajula RP, Chettiar ST, Williams RD, Thiyagarajan S, Kato Y, Aziz K, et al. The twist box domain is required for Twist1-induced prostate cancer metastasis. Mol Cancer Res MCR 2013;11:1387-400.

[26] Marín-Aguilera M, Codony-Servat J, Reig Ò, Lozano JJ, Fernández PL, Pereira MV, et al. Epithelial-to-mesenchymal transition mediates docetaxel resistance and high risk of relapse in prostate cancer. Mol Cancer Ther 2014;13:1270-84.

[27] Malouf GG, Taube JH, Lu Y, Roysarkar T, Panjarian S, Estecio MR, et al. Architecture of epigenetic reprogramming following Twist1-mediated epithelial-mesenchymal transition. Genome Biol 2013;14:R144.

[28] Mosquera JM, Beltran H, Park K, MacDonald TY, Robinson BD, Tagawa ST, et al. 
Concurrent AURKA and MYCN gene amplifications are harbingers of lethal treatmentrelated neuroendocrine prostate cancer. Neoplasia N Y N 2013;15:1-10.

[29] Börno ST, Fischer A, Kerick M, Fälth M, Laible M, Brase JC, et al. Genome-wide DNA methylation events in TMPRSS2-ERG fusion-negative prostate cancers implicate an EZH2dependent mechanism with miR-26a hypermethylation. Cancer Discov 2012;2:1024-35.

[30] Wang Q, Li W, Zhang Y, Yuan X, Xu K, Yu J, et al. Androgen receptor regulates a distinct transcription program in androgen-independent prostate cancer. Cell 2009;138:24556.

[31] Armstrong AJ, Eisenberger MA, Halabi S, Oudard S, Nanus DM, Petrylak DP, et al. Biomarkers in the management and treatment of men with metastatic castration-resistant prostate cancer. Eur Urol 2012;61:549-59.

[32] Scher HI, Morris MJ, Larson S, Heller G. Validation and clinical utility of prostate cancer biomarkers. Nat Rev Clin Oncol 2013;10:225-34.

[33] Goldkorn A, Ely B, Quinn DI, Tangen CM, Fink LM, Xu T, et al. Circulating tumor cell counts are prognostic of overall survival in SWOG S0421: a phase III trial of docetaxel with or without atrasentan for metastatic castration-resistant prostate cancer. J Clin Oncol 2014;32:1136-42.

[34] Scher HI, Beer TM, Higano CS, Anand A, Taplin M-E, Efstathiou E, et al. Antitumour activity of MDV3100 in castration-resistant prostate cancer: a phase 1-2 study. Lancet 2010;375:1437-46.

[35] Danila DC, Morris MJ, de Bono JS, Ryan CJ, Denmeade SR, Smith MR, et al. Phase II multicenter study of abiraterone acetate plus prednisone therapy in patients with docetaxeltreated castration-resistant prostate cancer. J Clin Oncol 2010;28:1496-501.

[36] Scher HI, Heller G, Molina A, Attard G, Danila DC, Jia X, et al. Circulating tumor cell biomarker panel as an individual-level surrogate for survival in metastatic castration-resistant prostate cancer. J Clin Oncol 2015;33:1348-55.

[37] Frenel JS, Carreira S, Goodall J, Roda D, Perez-Lopez R, Tunariu N, et al. Serial NextGeneration Sequencing of Circulating Cell-Free DNA Evaluating Tumor Clone Response To Molecularly Targeted Drug Administration. Clin Cancer Res 2015;21:4586-96.

[38] Azad AA, Volik SV, Wyatt AW, Haegert A, Le Bihan S, Bell RH, et al. Androgen Receptor Gene Aberrations in Circulating Cell-Free DNA: Biomarkers of Therapeutic Resistance in Castration-Resistant Prostate Cancer. Clin Cancer Res 2015;21:2315-24.

[39] Smaletz O, Scher HI, Small EJ, Verbel DA, McMillan A, Regan K, et al. Nomogram for overall survival of patients with progressive metastatic prostate cancer after castration. J Clin Oncol 2002;20:3972-82.

[40] Halabi S, Small EJ, Kantoff PW, Kattan MW, Kaplan EB, Dawson NA, et al. Prognostic 
model for predicting survival in men with hormone-refractory metastatic prostate cancer. $\mathrm{J}$ Clin Oncol 2003;21:1232-7.

[41] Halabi S, Lin C-Y, Kelly WK, Fizazi KS, Moul JW, Kaplan EB, et al. Updated prognostic model for predicting overall survival in first-line chemotherapy for patients with metastatic castration-resistant prostate cancer. J Clin Oncol Off J Am Soc Clin Oncol 2014;32:671-7.

[42] Pond GR, Sonpavde G, de Wit R, Eisenberger MA, Tannock IF, Armstrong AJ. The prognostic importance of metastatic site in men with metastatic castration-resistant prostate cancer. Eur Urol 2014;65:3-6.

[43] Ryan CJ, Molina A, Li J, Kheoh T, Small EJ, Haqq CM, et al. Serum androgens as prognostic biomarkers in castration-resistant prostate cancer: results from an analysis of a randomized phase III trial. J Clin Oncol 2013;31:2791-8.

[44] Ross RW, Galsky MD, Scher HI, Magidson J, Wassmann K, Lee G-SM, et al. A wholeblood RNA transcript-based prognostic model in men with castration-resistant prostate cancer: a prospective study. Lancet Oncol 2012;13:1105-13.

[45] Danila DC, Anand A, Schultz N, Heller G, Wan M, Sung CC, et al. Analytic and clinical validation of a prostate cancer-enhanced messenger RNA detection assay in whole blood as a prognostic biomarker for survival. Eur Urol 2014;65:1191-7.

[46] Ferraldeschi R, Nava Rodrigues D, Riisnaes R, Miranda S, Figueiredo I, Rescigno P, et al. PTEN protein loss and clinical outcome from castration-resistant prostate cancer treated with abiraterone acetate. Eur Urol 2015;67:795-802.

[47] Huang X, Yuan T, Liang M, Du M, Xia S, Dittmar R, et al. Exosomal miR-1290 and miR-375 as prognostic markers in castration-resistant prostate cancer. Eur Urol 2015;67:3341.

[48] Bitting RL, Armstrong AJ. Prognostic, predictive, and surrogate factors for individualizing treatment for men with castration-resistant prostate cancer. Am Soc Clin Oncol Educ Book 2012:292-7.

[49] Antonarakis ES, Lu C, Wang H, Luber B, Nakazawa M, Roeser JC, et al. AR-V7 and resistance to enzalutamide and abiraterone in prostate cancer. N Engl J Med 2014;371:102838.

[50] Schellhammer PF, Chodak G, Whitmore JB, Sims R, Frohlich MW, Kantoff PW. Lower baseline prostate-specific antigen is associated with a greater overall survival benefit from sipuleucel-T in the Immunotherapy for Prostate Adenocarcinoma Treatment (IMPACT) trial. Urology 2013;81:1297-302.

[51] Leibowitz-Amit R, Templeton AJ, Omlin A, Pezaro C, Atenafu EG, Keizman D, et al. Clinical variables associated with PSA response to abiraterone acetate in patients with metastatic castration-resistant prostate cancer. Ann Oncol 2014;25:657-62. 
[52] Morris MJ, Autio KA, Basch EM, Danila DC, Larson S, Scher HI. Monitoring the clinical outcomes in advanced prostate cancer: what imaging modalities and other markers are reliable? Semin Oncol 2013;40:375-92.

[53] Dennis ER, Jia X, Mezheritskiy IS, Stephenson RD, Schoder H, Fox JJ, et al. Bone scan index: a quantitative treatment response biomarker for castration-resistant metastatic prostate cancer. J Clin Oncol 2012;30:519-24.

[54] Sonpavde G, Pond GR, Templeton AJ, Fandi A, Tombal B, Rosenthal M, et al. Association Between RECIST Changes and Survival in Patients with Metastatic Castrationresistant Prostate Cancer Receiving Docetaxel. Eur Urol (In press).

[55] Scher HI, Halabi S, Tannock I, Morris M, Sternberg CN, Carducci MA, et al. Design and end points of clinical trials for patients with progressive prostate cancer and castrate levels of testosterone: recommendations of the Prostate Cancer Clinical Trials Working Group. J Clin Oncol 2008;26:1148-59.

[56] Loriot Y, Bianchini D, Ileana E, Sandhu S, Patrikidou A, Pezaro C, et al. Antitumour activity of abiraterone acetate against metastatic castration-resistant prostate cancer progressing after docetaxel and enzalutamide (MDV3100). Ann Oncol 2013;24:1807-12.

[57] Morris MJ, Molina A, Small EJ, de Bono JS, Logothetis CJ, Fizazi K, et al. Radiographic progression-free survival as a response biomarker in metastatic castration-resistant prostate cancer: COU-AA-302 results. J Clin Oncol 2015;33:1356-63.

[58] Noonan KL, North S, Bitting RL, Armstrong AJ, Ellard SL, Chi KN. Clinical activity of abiraterone acetate in patients with metastatic castration-resistant prostate cancer progressing after enzalutamide. Ann Oncol 2013;24:1802-7.

[59] Badrising S, van der Noort V, van Oort IM, van den Berg HP, Los M, Hamberg P, et al. Clinical activity and tolerability of enzalutamide (MDV3100) in patients with metastatic, castration-resistant prostate cancer who progress after docetaxel and abiraterone treatment. Cancer 2014;120:968-75. doi:10.1002/cncr.28518.

[60] Bianchini D, Lorente D, Rodriguez-Vida A, Omlin A, Pezaro C, Ferraldeschi R, et al. Antitumour activity of enzalutamide (MDV3100) in patients with metastatic castrationresistant prostate cancer (CRPC) pre-treated with docetaxel and abiraterone. Eur J Cancer 2014;50:78-84.

[61] Brasso K, Thomsen FB, Schrader AJ, Schmid SC, Lorente D, Retz M, et al. Enzalutamide Antitumour Activity Against Metastatic Castration-resistant Prostate Cancer Previously Treated with Docetaxel and Abiraterone: A Multicentre Analysis. Eur Urol 2015;68:317-24.

[62] Schmid SC, Geith A, Böker A, Tauber R, Seitz AK, Kuczyk M, et al. Enzalutamide after docetaxel and abiraterone therapy in metastatic castration-resistant prostate cancer. Adv Ther 2014;31:234-41. 
[63] Schrader AJ, Boegemann M, Ohlmann C-H, Schnoeller TJ, Krabbe L-M, Hajili T, et al. Enzalutamide in castration-resistant prostate cancer patients progressing after docetaxel and abiraterone. Eur Urol 2014;65:30-6.

[64] Thomsen FB, Røder MA, Rathenborg P, Brasso K, Borre M, Iversen P. Enzalutamide treatment in patients with metastatic castration-resistant prostate cancer progressing after chemotherapy and abiraterone acetate. Scand J Urol 2014;48:268-75.

[65] Mostaghel EA, Marck BT, Plymate SR, Vessella RL, Balk S, Matsumoto AM, et al. Resistance to CYP17A1 inhibition with abiraterone in castration-resistant prostate cancer: induction of steroidogenesis and androgen receptor splice variants. Clin Cancer Res 2011;17:5913-25.

[66] Hu R, Lu C, Mostaghel EA, Yegnasubramanian S, Gurel M, Tannahill C, et al. Distinct transcriptional programs mediated by the ligand-dependent full-length androgen receptor and its splice variants in castration-resistant prostate cancer. Cancer Res 2012;72:3457-62.

[67] Omlin A, Pezaro CJ, Zaidi S, Lorente D, Mukherji D, Bianchini D, et al. Antitumour activity of abiraterone and diethylstilboestrol when administered sequentially to men with castration-resistant prostate cancer. Br J Cancer 2013;109:1079-84.

[68] Pezaro CJ, Omlin AG, Altavilla A, Lorente D, Ferraldeschi R, Bianchini D, et al. Activity of cabazitaxel in castration-resistant prostate cancer progressing after docetaxel and next-generation endocrine agents. Eur Uro1 2014;66:459-65.

[69] Al Nakouzi N, Le Moulec S, Albigès L, Wang C, Beuzeboc P, Gross-Goupil M, et al. Cabazitaxel Remains Active in Patients Progressing After Docetaxel Followed by Novel Androgen Receptor Pathway Targeted Therapies. Eur Urol 2015;68:228-35.

[70] Houts AC, Hennessy D, Walker MS, Nicacio L, Thompson SF, Miller PJ, et al. Treatment patterns and clinical effectiveness in metastatic castrate resistant prostate cancer after first-line docetaxel. J Community Support Oncol 2014;12:321-8.

[71] Sella A, Sella T, Peer A, Berger R, Frank SJ, Gez E, et al. Activity of cabazitaxel after docetaxel and abiraterone acetate therapy in patients with castration-resistant prostate cancer. Clin Genitourin Cancer 2014;12:428-32.

[72] Zhu M-L, Horbinski CM, Garzotto M, Qian DZ, Beer TM, Kyprianou N. Tubulintargeting chemotherapy impairs androgen receptor activity in prostate cancer. Cancer Res 2010;70:7992-8002.

[73] Onstenk W, Sieuwerts AM, Kraan J, Van M, Nieuweboer AJM, Mathijssen RHJ, et al. Efficacy of Cabazitaxel in Castration-resistant Prostate Cancer Is Independent of the Presence of AR-V7 in Circulating Tumor Cells. Eur Urol 2015;68:939-45.

[74] Aggarwal R, Harris A, Formaker C, Small EJ, Molina A, Griffin TW, et al. Response to subsequent docetaxel in a patient cohort with metastatic castration-resistant prostate cancer after abiraterone acetate treatment. Clin Genitourin Cancer 2014;12:e167-72. 
[75] Azad AA, Leibowitz-Amit R, Eigl BJ, Lester R, Wells JC, Murray RN, et al. A retrospective, Canadian multi-center study examining the impact of prior response to abiraterone acetate on efficacy of docetaxel in metastatic castration-resistant prostate cancer. The Prostate 2014;74:1544-50.

[76] Mezynski J, Pezaro C, Bianchini D, Zivi A, Sandhu S, Thompson E, et al. Antitumour activity of docetaxel following treatment with the CYP17A1 inhibitor abiraterone: clinical evidence for cross-resistance? Ann Oncol 2012;23:2943-7.

[77] Schweizer MT, Zhou XC, Wang H, Bassi S, Carducci MA, Eisenberger MA, et al. The influence of prior abiraterone treatment on the clinical activity of docetaxel in men with metastatic castration-resistant prostate cancer. Eur Urol 2014;66:646-52.

[78] Suzman DL, Luber B, Schweizer MT, Nadal R, Antonarakis ES. Clinical activity of enzalutamide versus docetaxel in men with castration-resistant prostate cancer progressing after abiraterone. The Prostate 2014;74:1278-85.

[79] Caffo O, De Giorgi U, Fratino L, Alesini D, Zagonel V, Facchini G, et al. Clinical Outcomes of Castration-resistant Prostate Cancer Treatments Administered as Third or Fourth Line Following Failure of Docetaxel and Other Second-line Treatment: Results of an Italian Multicentre Study. Eur Urol 2015;68:147-53.

[80] Shore ND, Chowdhury S, Villers A, Klotz L, Siemens DR, Phung D, et al. Efficacy and safety of enzalutamide versus bicalutamide for patients with metastatic prostate cancer (TERRAIN): a randomised, double-blind, phase 2 study. Lancet Oncol 2016.

[81] Sweeney CJ, Chen Y-H, Carducci M, Liu G, Jarrard DF, Eisenberger M, et al. Chemohormonal Therapy in Metastatic Hormone-Sensitive Prostate Cancer. N Engl J Med 2015;373:737-46. doi:10.1056/NEJMoa1503747.

[82] James ND, Sydes MR, Clarke NW, Mason MD, Dearnaley DP, Spears MR, et al. Addition of docetaxel, zoledronic acid, or both to first-line long-term hormone therapy in prostate cancer (STAMPEDE): survival results from an adaptive, multiarm, multistage, platform randomised controlled trial. Lancet Lond Engl 2016;387:1163-77.

[83] Mohler JL, Armstrong AJ, Bahnson RR, D'Amico AV, Davis BJ, Eastham JA, et al. Prostate Cancer, Version 1.2016. J Natl Compr Cancer Netw JNCCN 2016;14:19-30.

[84] Gravis G, Boher J-M, Joly F, Soulié M, Albiges L, Priou F, et al. Androgen Deprivation Therapy (ADT) Plus Docetaxel Versus ADT Alone in Metastatic Non castrate Prostate Cancer: Impact of Metastatic Burden and Long-term Survival Analysis of the Randomized Phase 3 GETUG-AFU15 Trial. Eur Urol (In press)

[85] Francini E, Sweeney CJ. Docetaxel Activity in the Era of Life-prolonging Hormonal Therapies for Metastatic Castration-resistant Prostate Cancer. Eur Urol (In press)

[86] Massard C, Penttinen HM, Vjaters E, Bono P, Lietuvietis V, Tammela TL, et al. Pharmacokinetics, Antitumor Activity, and Safety of ODM-201 in Patients with 
Chemotherapy-naive Metastatic Castration-resistant Prostate Cancer: An Open-label Phase 1 Study. Eur Urol (In press)

[87] Canesin G, Evans-Axelsson S, Hellsten R, Sterner O, Krzyzanowska A, Andersson T, et al. The STAT3 Inhibitor Galiellalactone Effectively Reduces Tumor Growth and Metastatic Spread in an Orthotopic Xenograft Mouse Model of Prostate Cancer. Eur Urol (In press)

[88] Marques RB, Aghai A, de Ridder CMA, Stuurman D, Hoeben S, Boer A, et al. High Efficacy of Combination Therapy Using PI3K/AKT Inhibitors with Androgen Deprivation in Prostate Cancer Preclinical Models. Eur Urol 2015;67:1177-85.

[89] Lorente D, Mateo J, Perez-Lopez R, de Bono JS, Attard G. Sequencing of agents in castration-resistant prostate cancer. Lancet Oncol 2015;16:e279-92.

[90] Jones RJ. Sequencing systemic therapies in advanced prostate cancer: spoiled for choice but not for evidence. Eur Urol 2014;66:466-7. 


\section{Review criteria}

A search of original and review articles focusing on the conservative management of upper tract urothelial carcinoma was performed in MEDLINE and PubMed. The following search terms ("Prostate cancer") AND ("Castration" OR "Castrate") AND ("Resistant" OR "Resistance") were used according a free text protocol that applied only "Humans" and "English language" filters without a time-period restriction. Reference lists of selected articles were cross-searched for additional literature. 
Figure 1: Androgens receptor axis and action sites of news hormonal agents in CRPC adapted from Kohli et al[12]

Figure 2: Genomic lesions in evolution of prostate cancer adapted from Barbieri et al.[1] Genes with common genomic lesions \{including mutation, rearrangement, or copy number alteration) are shown. Solid arrows designate a temporal relationship between events; presumptive "early" lesions are at the top, with "later" lesions below. Tumors with ETS fusions (ETS+) are shown on the top; ETS- tumors are shown on the bottom.

ADT: androgen deprivation therapy.

\section{Figure 3A: Molecular history of prostate cancer evolution.}

The progression to the CRPC stage, is usually describe at the molecular level, step by step, involving mainly chromosomal rearrangements, according the model of the punctuated progression named of chromoplexy. A shortcut to metastatic and resistant stages, related to a high genetic instability with numerous chromosomal rearrangements "chromotripsis" and hypermutational status "kaetagis" can occur.

Figure 3B: Mechanisms of CRPC progression driven by heterogeneous modalities of androgen receptor deregulation.

CRPC related to an uncontrolled Androgen receptor (AR) have been related to heterogeneous mechanisms (residual ligands to AR, promiscuous activation involving AR expression and structure or Co-activators). AR activation pathway (AR+ signature) drives genes regulated by androgen responses elements, such as PSA or AR dependant fusions genes classified as type 1,2 or 5 (such as TMPRSS2-ETS). 
Supplemental Figure 1: PCa progression and phenomenon of chromoplexy and chromotripsis in prostate cancer evolution, adapted from Bacca et al.[17]

Concept of Genomic Evolution of Prostate Cancer: Three different situations could occur: gradual accumulation in cancer genome of aberrations (upper curve), punctuated progression/chromoplexy (middle), or single catastrophic event/ chromotripsis (lower curve). Larger-scale rearrangements that affect broader swaths of the genome may be more difficult for a cell to survive and may tend to require co-occurring oncogenic lesions to become fixed in a tumor.

\section{Supplemental Figure 2A: Ontogenic origins of prostate cells}

Androgen receptor drives luminal differentiation (and PSA expression) phenotype during development of prostatic gland and during progression of CRPC. Cell survival without androgen receptor activation is associated to a phenotype switch to neuroendocrine or stem cell like phenotypes according ontogenic origin of prostatic glands. CPCR is a heterogeneous disease involving accumulation of mutations or epigenic changes in cancerous cells. So, CPCR exhibits various phenotypes which are able to suggest a biological classification.

\section{Supplemental Figure 2B: Bio-pathological classification of CRPC}

On one hand CPCR could be secretory (expressing luminal markers such as PSA) or neuroendocrine markers such as chromogranin A. On the other hand, CPCR could be nonsecretory, expressing stem cells' markers such as CD44/aldehyde dehydrogenase 1A1, like neuroendocrine phenotype they do not express AR and his "reporter" gene PSA.CRPC with high level of PSA expression are determined by an uncontrolled androgen activity which 
could be driven by residual androgens (potential responder to a depth androgen withdrawal) or AR mutation leading to a constitutive oncogenic activation.

AR: androgen receptor; PSA: Prostate Specific Antigen; NSE: Neuro Specific Enolase; VP16: etoposide

Supplemental Figure 3: Options of targeting CRPC according to the activation of androgen receptors.

If AR pathway is activated, AA or ENZ might be the first option therapy to propose. If the CRPC become independent from the AR signaling, many pathways have to be explored including targeting the immune system, EMT, epigenetics, growth factor receptors or antimitotic agents. 


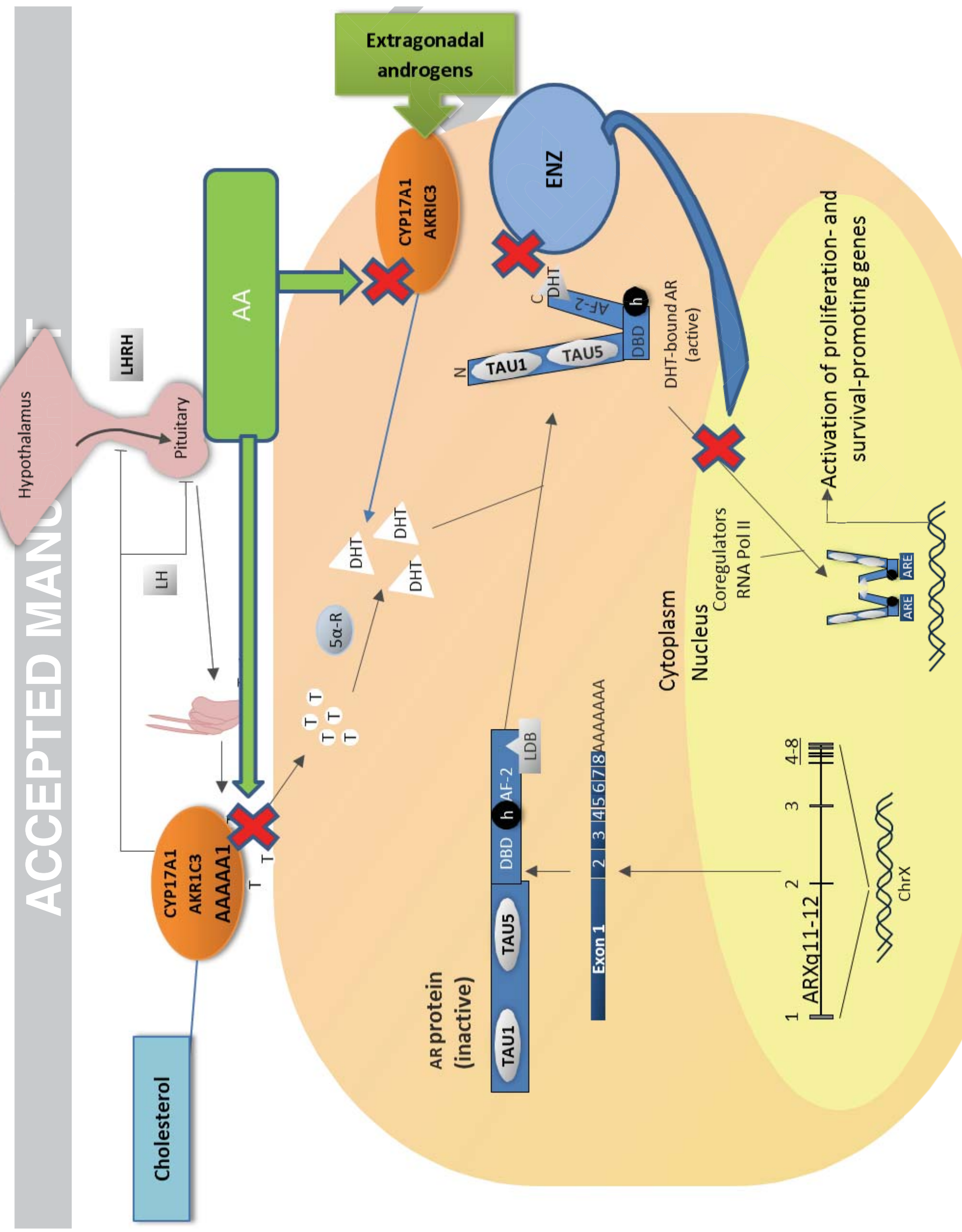




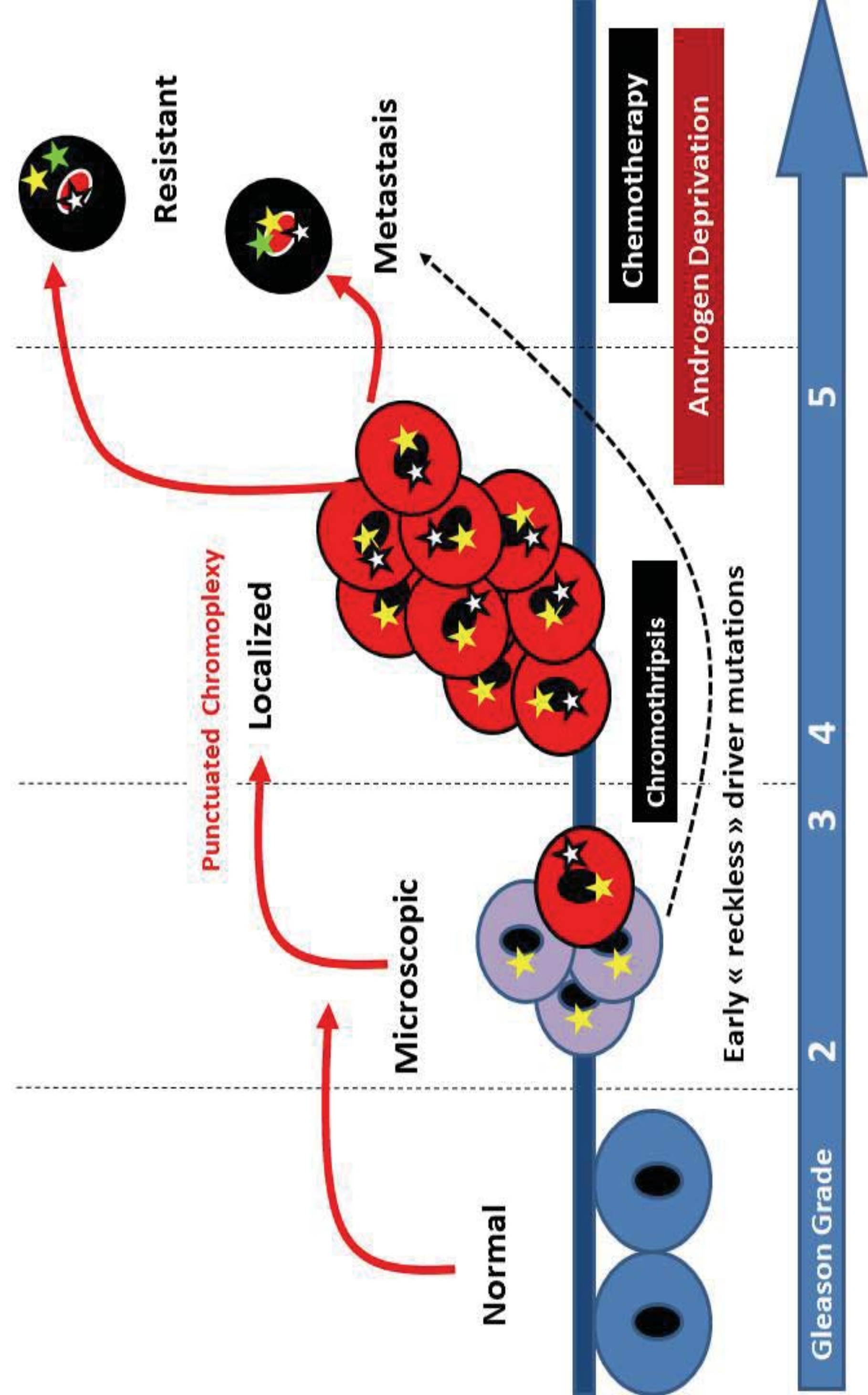



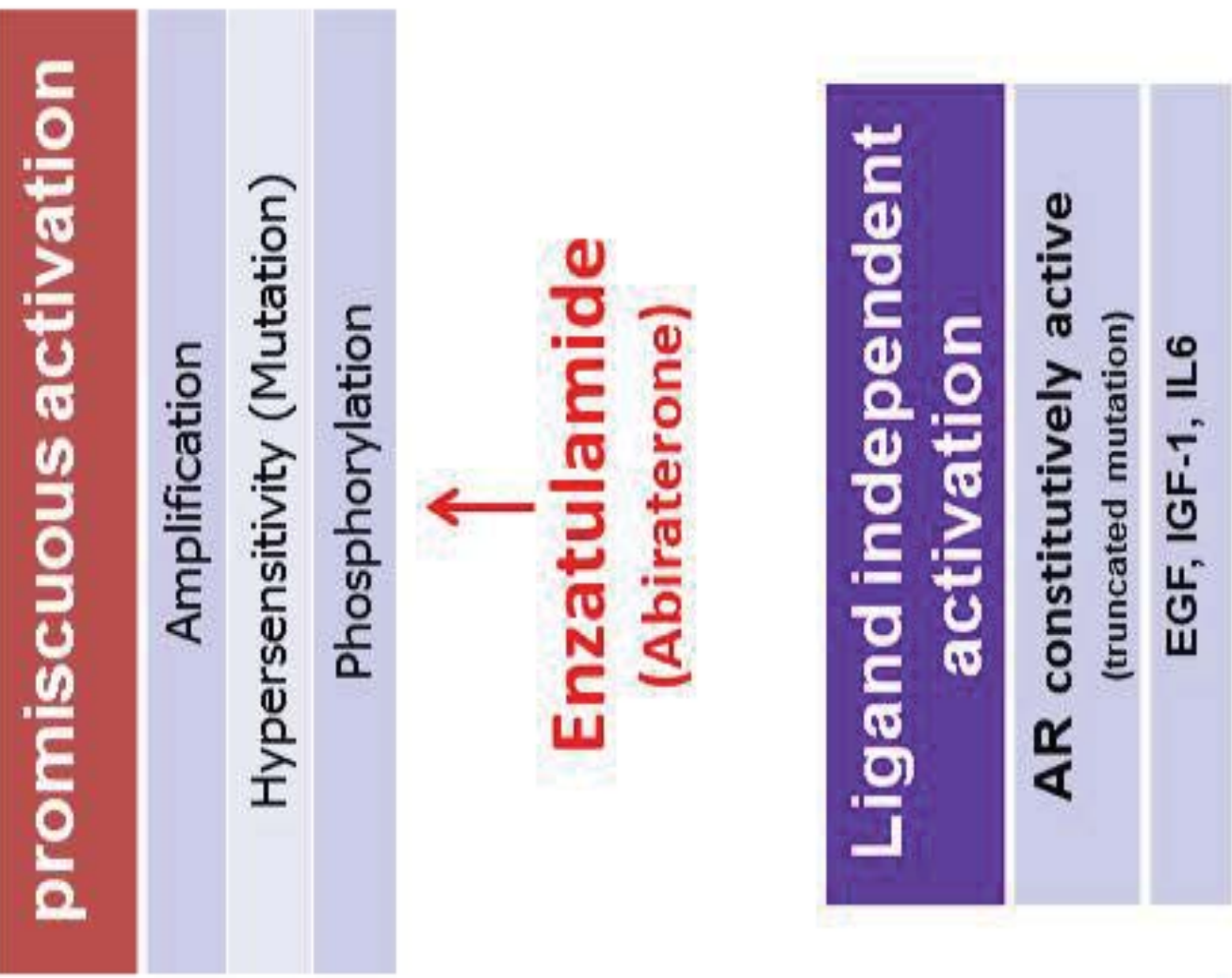

$+$
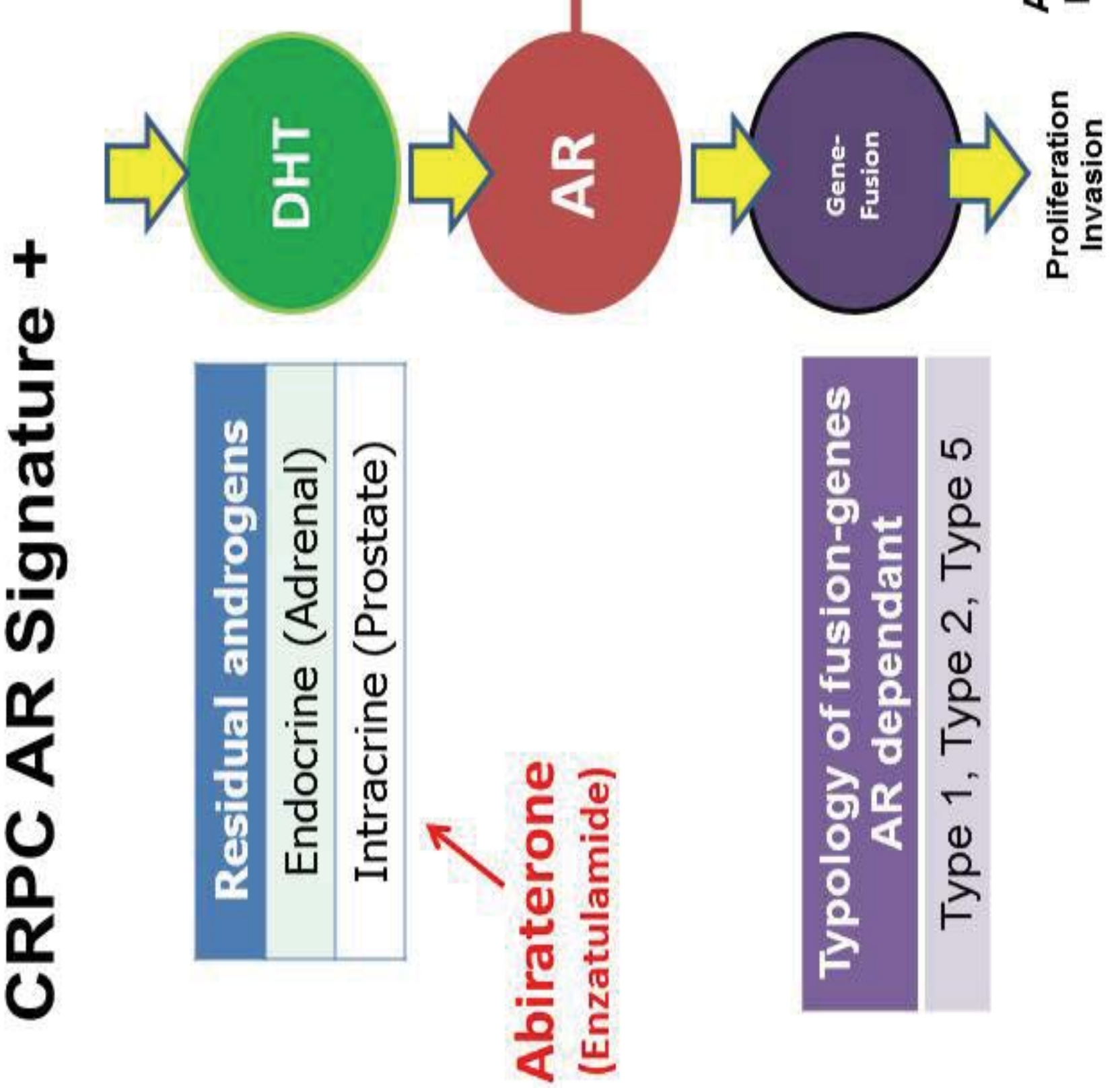
Table 1: Pre and post-treatment prognostic biomarkers in CRPC.

\begin{tabular}{|c|c|c|}
\hline & $\begin{array}{c}\text { Pre-treatment prognostic } \\
\text { biomarkers }\end{array}$ & $\begin{array}{c}\text { Post-treatment prognostic } \\
\text { biomarkers }\end{array}$ \\
\hline $\begin{array}{l}\text { Clinical parameters } \\
\text { and primary tumor } \\
\text { characteristics at } \\
\text { baseline }\end{array}$ & $\begin{array}{l}\text { Age } \\
\text { Performance Status } \\
\text { Pain } \\
\text { Gleason score, Gleason sum } \\
\text { Number of metastatic sites } \\
\text { Bone metastases } \\
\text { Liver metastases }\end{array}$ & $\begin{array}{l}\text { Pain improvement } \\
\text { Quality of life improv }\end{array}$ \\
\hline Biological parameters & $\begin{array}{l}\text { Total PSA and PSA kinetics } \\
\text { Hemoglobin } \\
\text { LDH, ALP } \\
\text { Albumin } \\
\text { CTCs } \\
\text { VEGF, IL6, Chromogranin A } \\
\text { CRP } \\
\text { Bone turnover markers } \\
\text { Urinary N -Telopeptide }\end{array}$ & $\begin{array}{l}\text { PSA decline } \\
\text { Change in CTCs count }(\geq 5 \text { to }<5 \text { ) } \\
\text { Anemia } \\
\text { LDH changes } \\
\text { ALP changes } \\
\text { Induction of immunity to tumor } \\
\text { antigens (Sipuleucel-T) }\end{array}$ \\
\hline Type of progression & PSA only, bone, measurable lesions & Skeletal events, rPFS \\
\hline
\end{tabular}

PSA: prostate specific antigen; LDH: Lactate dehydrogenase; ALP: Alkaline phosphatase; CTCs: circulating tumor cells; rPFS: radiologic progression-free survival. 
Table 2: Biomarkers with potential predictive value on response, patients benefit and candidate for surrogate end-points.

\begin{tabular}{|l|l|}
\hline \multicolumn{1}{|c|}{ Biomarker } & \multicolumn{1}{c|}{ Main problematic } \\
\hline PSA decline & $\begin{array}{l}\text { Some new agents demonstrated an OS benefit without any PSA change } \\
\text { Threshold of decline unclear (decrease of 30\% or 50\%) }\end{array}$ \\
\hline Baseline PSA & Low value at baseline is associated with greater OS only in Sipuleucel-T phase III trial \\
\hline Composite score & $\begin{array}{l}\text { Association of PSA response over 50\%, neutrophil-to lymphocyte ratio } \leq 5 \text { and low value } \\
\text { of LDH seems to be predictive of only abiraterone acetate response and OS }\end{array}$ \\
\hline Pain improvement & $\begin{array}{l}\text { Subject to change with analgesic treatment alone } \\
\text { Causes of pain independent of tumor progression } \\
\text { Reliable validated scales to be validated }\end{array}$ \\
\hline Quality of life & Definition of clinically significant changes \\
\hline Bone turn-over markers & $\begin{array}{l}\text { Normal in patients with visceral-only or node-only disease and in some with bone } \\
\text { metastasis } \\
\text { Normalization of high baseline ALP value seems to be an independent predictive factor for } \\
\text { OS in patients with bone metastases treated with chemotherapy }\end{array}$ \\
\hline CTCs & $\begin{array}{l}\text { Only 50\% of patients having detectable CTCs using the FDA approved Cell Search } \\
\text { platform } \\
\text { Unable to be banked or stored; expensive procedure in specialized labs only }\end{array}$ \\
\hline Radiographic response & $\begin{array}{l}\text { Bone metastases are not considered by RECIST as measurable target lesions } \\
\text { Bone scans flare } \\
\text { Modest correlation with OS }\end{array}$ \\
\hline PFS & $\begin{array}{l}\text { No correlation between PFS and OS for Sipuleucel-T } \\
\text { Anti-angiogenic agents improved PFS without OS increase }\end{array}$ \\
\hline
\end{tabular}

PSA: prostate specific antigen; CTCs: circulating tumor cells; OS: overall survival; LDH: Lactate dehydrogenase; ALP: Alkaline phosphatase; PFS: progression free survival 
Table 3: Studies reporting the outcomes of treatment sequencing in castration-resistant prostate cancer

\begin{tabular}{|c|c|c|c|c|c|c|}
\hline Study & Study design & $\begin{array}{l}\text { Number of } \\
\text { patients }\end{array}$ & $\begin{array}{c}\text { PSA } \\
\text { response } \\
\geq \mathbf{5 0 \%}, \% \\
\end{array}$ & $\begin{array}{c}\text { Partial } \\
\text { radiographic } \\
\text { response, \% }\end{array}$ & $\begin{array}{l}\text { Median } \\
\text { PFS, } \\
\text { months }\end{array}$ & $\begin{array}{l}\text { Median } \\
\text { OS, } \\
\text { months }\end{array}$ \\
\hline \multicolumn{7}{|c|}{ Abiraterone acetate after docetaxel and enzalutamide } \\
\hline $\begin{array}{l}\text { Loriot et al., } \\
2013 \text { [56] }\end{array}$ & Retrospective & 38 & 8 & 8 & 2.7 & \\
\hline $\begin{array}{l}\text { Noonan et al., } \\
2013 \text { [58] }\end{array}$ & Retrospective & 30 & 4 & 0 & 3.6 & 11.6 \\
\hline \multicolumn{7}{|c|}{ Enzalutamide after docetaxel and abiraterone acetate } \\
\hline $\begin{array}{l}\text { Badrising et al., } \\
2014 \text { [59] }\end{array}$ & Retrospective & 61 & 21 & NR & 2.8 & 7.3 \\
\hline $\begin{array}{l}\text { Bianchini et al., } \\
2014 \text { [60] }\end{array}$ & Retrospective & 39 & 13 & 4 & 2.8 & $\begin{array}{c}\text { Not } \\
\text { reached }\end{array}$ \\
\hline $\begin{array}{l}\text { Brasso et al., } \\
2014 \text { [61] }\end{array}$ & Retrospective & 137 & 18 & 12 & 3.1 & 8.3 \\
\hline $\begin{array}{l}\text { Schmid et al., } \\
2014 \text { [62] }\end{array}$ & Prospective & 35 & 10 & & 3.1 & 7.5 \\
\hline $\begin{array}{l}\text { Schrader et al., } \\
2014 \text { [63] }\end{array}$ & Retrospective & 35 & 29 & 6 & NR & 7.1 \\
\hline $\begin{array}{l}\text { Thomsen et al., } \\
2014 \text { [64] }\end{array}$ & Retrospective & 24 & 17 & NR & NR & 4.8 \\
\hline \multicolumn{7}{|c|}{ Cabazitaxel after docetaxel and abiraterone acetate or enzalutamide } \\
\hline $\begin{array}{l}\text { Pezaro et al., } \\
2013 \text { [68] }\end{array}$ & Retrospective & 37 & 41 & 15 & 5.5 & 20.3 \\
\hline $\begin{array}{l}\text { Al Nakouzi et } \\
\text { al., } 2014 \text { [69] }\end{array}$ & Retrospective & & 35 & NR & 4.4 & 10.9 \\
\hline $\begin{array}{l}\text { Houts et al., } \\
2014 \text { [70] }\end{array}$ & Retrospective & & NR & NR & 4.9 & NR \\
\hline $\begin{array}{l}\text { Sella et al., } 2014 \\
\text { [71] }\end{array}$ & Retrospective & 24 & 32 & 15 & 3.2 & 8.2 \\
\hline \multicolumn{7}{|c|}{ Docetaxel after abiraterone acetate } \\
\hline $\begin{array}{l}\text { Aggarwal et al., } \\
2014 \text { [74] }\end{array}$ & Retrospective & 23 & 48 & NR & NR & 12.4 \\
\hline $\begin{array}{l}\text { Azad et al., } 2014 \\
\text { [75] }\end{array}$ & Retrospective & 86 & 35 & NR & 4.0 & 11.7 \\
\hline $\begin{array}{l}\text { Mezynski et al., } \\
2014[76]\end{array}$ & Retrospective & 35 & 26 & 17 & NR & 12.5 \\
\hline $\begin{array}{l}\text { Houts et al., } \\
2014 \text { [70] }\end{array}$ & Retrospective & 71 & NR & NR & 7.8 & 10.6 \\
\hline $\begin{array}{l}\text { Schweizer et al., } \\
2014 \text { [77] }\end{array}$ & Retrospective & 24 & 38 & NR & 4.4 & NR \\
\hline $\begin{array}{l}\text { Suzman et al., } \\
2014 \text { [78] }\end{array}$ & Retrospective & 31 & 40 & NR & 4.4 & NR \\
\hline
\end{tabular}




\section{Highlights}

1. Chromoplexy and chromotripsis models for CRPC genmoic landscape

2. Dependent and independent androgen receptor activity pathways in CRPC development

3. No biomarker validated as a surrogate for overall survival in CRPC patients

4. AR-V7 splice variant to predict resistance to abiraterone and enzalutamide in CRPC.

5. Only rational treatment sequencing can be currently advised for CRPC. 